\title{
Epoxide hydrolases are not only a molecular sponge sucking up genotoxic epoxides: new roles in control of blood pressure, inflammation as well as nociception and cell proliferation
}

\author{
J. G. Hengstler $\cdot$ J. D. Stewart $\cdot$ H. M. Bolt
}

Published online: 31 March 2009

(C) Springer-Verlag 2009

Recently, the Archives of Toxicology have started a series of review articles about xenobiotic metabolizing enzymes, systematically addressing nomenclature and gene evolution, catalytic mechanisms, toxicological relevance, and polymorphisms (Bolt and Hengstler 2008). Olavi Pelkonen has already reviewed cytochrome P450 enzymes (Pelkonen et al. 2008) and CP Strassburg and TO Lankisch have contributed comprehensive articles about UDP-glucuronosyltransferases (Strassburg et al. 2008; Lankisch et al. 2008).

We are happy that Michael Arand, Annette Cronin and Martina Decker from the University of Zürich continued our series of review articles about drug-metabolizing enzymes with an excellent contribution about mammalian epoxide hydrolases (Decker et al. 2009, this issue). Traditionally, epoxide hydrolases are known as primarily detoxifying enzymes that catalyze the hydrolysis of epoxides (Hengstler et al. 1998). Importantly, epoxide hydrolases act by a two-step reaction, which has some important implications. In a first step, two tyrosines in the catalytic center of the enzyme bind the epoxide by hydrogen bonding to the ring oxygen, and an aspartic acid residue attacks a carbon atom of the oxirane ring (Oesch et al. 2000, 2001). Simultaneously, the bond of this carbon is released and an ester intermediate is formed. In a second step, the covalent intermediate is hydrolyzed and the detoxified product of the epoxide hydrolase reaction is released. Importantly, the formation of the ester intermediate (step 1) proceeds by three orders of magnitudes faster than the subsequent hydrolysis

J. G. Hengstler $(\square) \cdot$ J. D. Stewart · H. M. Bolt Leibniz-Institut für Arbeitsforschung an der TU Dortmund, Leibniz Research Centre for Working Environment and Human Factors (IfADo), Ardeystrasse 67, 44139 Dortmund, Germany e-mail: hengstler@ifado.de (step 2). Therefore, epoxide hydrolases may act like a molecular sponge that binds and inactivates dangerous epoxides rapidly, whereas the subsequent release of the product occurs only slowly (Oesch et al. 2001). This explains why epoxide hydrolases can keep tissue concentrations of free epoxides very low up to concentrations of epoxides where the epoxide hydrolases are titrated out leading to a sudden burst of the epoxides. This sponge effect contributes to threshold mechanisms observed for some genotoxic epoxides (Oesch et al. 2001; Hengstler et al. 2003, 1997).

However, in their current review Decker et al. (2009) show that mammalian epoxide hydrolases are more than just a sponge for genotoxic waste. The authors collected convincing evidence that epoxide hydrolases are also involved in control of the following functions:

- blood pressure

- inflammation and nociception

- participation of signal transduction processes relevant for cell proliferation

- control of adult respiratory distress syndrome and multiorgan failure.

Cutting edge topics of our journal are drug metabolism (Borza et al. 2008; Hengstler and Bolt 2008; Glahn et al. 2008; Gundert-Remy and Hengstler 2008; Binner et al. 2008; Naraharisetti et al. 2008; Rudolf et al. 2008; Fisher et al. 2008; Mitchell et al. 2007) control of genotoxic intermediates (Adam and Laufs 2008; Verstraeten et al. 2008; Puntel et al. 2008; Settels et al. 2008; Lindström et al. 2008; Wong et al. 2008) and in vitro systems to simulate in vivo metabolism (Schug et al. 2008; Hewitt et al. 2007; Sugihara et al. 2008). Therefore, epoxide hydrolases represent a traditional focus of our journal (Srivastava et al. 2008; Cornelis et al. 2007; Wenghoefer et al. 2003; Friedberg 
et al. 1989; Pacifici et al. 1988). What makes the current review so attractive is its demonstration that an enzyme family traditionally believed to be limited to detoxifying functions also plays a relevant role in processes such as vasodilation, inflammation, and proliferation.

\section{References}

Adam O, Laufs U (2008) Antioxidative effects of statins. Arch Toxicol $82: 885-892$

Binner C, Selinski S, Barysch MJ, Pölcher C, Schormann W, Hermes M, Brulport M, Bauer A, Rudolph C, Bedawy E, Schug M, Golka K, Hasenclever D, Trauer H, Lessig R, Bolt HM, Ickstadt K, Hengstler JG (2008) Munich Oktoberfest experience: remarkable impact of sex and age in ethanol intoxication. Arch Toxicol 82:933-939

Bolt HM, Hengstler JG (2008) A new series of review articles on drug metabolizing enzymes: nomenclature of isoenzyme families, genetic organization, polymorphisms, substrate specificities, clinical relevance and role in carcinogenesis. Arch Toxicol 82:413414

Borza A, Plöttner S, Wolf A, Behm C, Selinski S, Hengstler JG, Roos PH, Bolt HM, Kuhlmann J, Föllmann W (2008) Synergism of aromatic amines and benzo[a]pyrene in induction of Ah receptordependent genes. Arch Toxicol 82:973-980

Cornelis MC, El-Sohemy A, Campos H (2007) Microsomal epoxide hydrolase genotype and risk of myocardial infarction. Arch Toxicol 81:641-645

Decker M, Arand M, Cronin A (2009) Mammalian epoxide hydrolases in xenobiotic metabolism and signalling. Arch Toxicol (in press)

Fisher CD, Jackson JP, Lickteig AJ, Augustine LM, Cherrington NJ (2008) Drug metabolizing enzyme induction pathways in experimental non-alcoholic steatohepatitis. Arch Toxicol 82:959-964

Friedberg T, Timms C, Kissel W, Oesch F (1989) Evidence for several hepatic proteins related to microsomal epoxide hydrolase. Arch Toxicol Suppl 13:145-152

Glahn F, Schmidt-Heck W, Zellmer S, Guthke R, Wiese J, Golka K, Hergenröder R, Degen GH, Lehmann T, Hermes M, Schormann W, Brulport M, Bauer A, Bedawy E, Gebhardt R, Hengstler JG, Foth H (2008) Cadmium, cobalt and lead cause stress response, cell cycle deregulation and increased steroid as well as xenobiotic metabolism in primary normal human bronchial epithelial cells which is coordinated by at least nine transcription factors. Arch Toxicol 82:513-524

Gundert-Remy U, Hengstler JG (2008) Primary rat hepatocytes as in vitro system for gene expression studies: comparison of sandwich, Matrigel and 2D cultures. Arch Toxicol 82:923-931

Hengstler JG, Bolt HM (2008) Failure in drug development: the role of inhibition and induction of cytochrome P450 enzymes. Arch Toxicol 82:665-666

Hengstler JG, Arand M, Herrero ME, Oesch F (1998) Polymorphisms of $N$-acetyltransferases, glutathione $S$-transferases, microsomal epoxide hydrolase and sulfotransferases: influence on cancer susceptibility. Recent results. In: Schwab M (ed) Genes and environment. Springer, New York. Cancer Res 154:47-85

Hengstler JG, Bogdanffy MS, Bolt HM, Oesch F (2003) Challenging dogma: thresholds for genotoxic carcinogens? The case of vinyl acetate. Annu Rev Pharmacol Toxicol 43:485-520

Herrero ME, Arand M, Hengstler JG, Oesch F (1997) Recombinant expression of human microsomal epoxide hydrolase protects V79 Chinese hamster cells from styrene oxide- but not from ethylene oxide-induced DNA strand breaks. Environ Mol Mutagen 30:429-439
Hewitt NJ, Lechón MJ, Houston JB, Hallifax D, Brown HS, Maurel P, Kenna JG, Gustavsson L, Lohmann C, Skonberg C, Guillouzo A, Tuschl G, Li AP, LeCluyse E, Groothuis GM, Hengstler JG (2007) Primary hepatocytes: current understanding of the regulation of metabolic enzymes and transporter proteins, and pharmaceutical practice for the use of hepatocytes in metabolism, enzyme induction, transporter, clearance, and hepatotoxicity studies. Drug Metab Rev 39:159-234

Lankisch TO, Gillman TC, Erichsen TJ, Ehmer U, Kalthoff S, Freiberg N, Munzel PA, Manns MP, Strassburg CP (2008) Aryl hydrocarbon receptor-mediated regulation of the human estrogen and bile acid UDP-glucuronosyltransferase 1A3 gene. Arch Toxicol 82:573-582

Lindström V, Brandt I, Lindhe O (2008) Species differences in 3-methylsulphonyl-DDE bioactivation by adrenocortical tissue. Arch Toxicol 82:159-163

Mitchell AE, Burns SA, Rudolf JL (2007) Isozyme- and gender-specific induction of glutathione $S$-transferases by flavonoids. Arch Toxicol 81:777-784

Naraharisetti SB, Aggarwal M, Sarkar SN, Malik JK (2008) Concurrent subacute exposure to arsenic through drinking water and malathion via diet in male rats: effects on hepatic drug-metabolizing enzymes. Arch Toxicol 82:543-551

Oesch F, Herrero ME, Hengstler JG, Lohmann M, Arand M (2000) Metabolic detoxification: implications for thresholds. Toxicol Pathol 28:382-387

Oesch F, Herrero ME, Lohmann M, Hengstler JG, Arand M (2001) Sequestration of biological reactive intermediates by trapping as covalent enzyme-intermediate complex. Adv Exp Med Biol 500:577-586

Pacifici GM, Temellini A, Giuliani L, Rane A, Thomas H, Oesch F (1988) Cytosolic epoxide hydrolase in humans: development and tissue distribution. Arch Toxicol 62:254-257

Pelkonen O, Turpeinen M, Hakkola J, Honkakoski P, Hukkanen J, Raunio H (2008) Inhibition and induction of human cytochrome P450 enzymes: current status. Arch Toxicol 82:667-715

Puntel GO, Gubert P, Peres GL, Bresolin L, Rocha JB, Pereira ME, Carratu VS, Soares FA (2008) Antioxidant properties of oxime 3(phenylhydrazono) butan-2-one. Arch Toxicol 82:755-762

Rudolf JL, Bauerly KA, Tchaparian E, Rucker RB, Mitchell AE (2008) The influence of diet composition on phase I and II biotransformation enzyme induction. Arch Toxicol 82:893-901

Schug M, Heise T, Bauer A, Storm D, Blaszkewicz M, Bedawy E, Brulport M, Geppert B, Hermes M, Föllmann W, Rapp K, Maccoux L, Schormann W, Appel KE, Oberemm A, Settels E, Bernauer U, Palavinskas R, Klaffke HS, Gundert-Remy U, Appel KE (2008) Human CYP2E1 mediates the formation of glycidamide from acrylamide. Arch Toxicol 82:717-727

Srivastava DS, Mandhani A, Mittal RD (2008) Genetic polymorphisms of cytochrome P450 CYP1A1 $(* 2 \mathrm{~A})$ and microsomal epoxide hydrolase gene, interactions with tobacco-users, and susceptibility to bladder cancer: a study from North India. Arch Toxicol 82:633-639

Strassburg CP, Lankisch TO, Manns MP, Ehmer U (2008) Family 1 uridine-5' -diphosphate glucuronosyltransferases (UGT1A): from Gilbert's syndrome to genetic organization and variability. Arch Toxicol 82:415-433

Sugihara K, Okayama T, Kitamura S, Yamashita K, Yasuda M, Miyairi S, Minobe Y, Ohta S (2008) Comparative study of aryl hydrocarbon receptor ligand activities of six chemicals in vitro and in vivo. Arch Toxicol 82:5-11

Verstraeten SV, Aimo L, Oteiza PI (2008) Aluminium and lead: molecular mechanisms of brain toxicity. Arch Toxicol 82:789802

Wenghoefer M, Pesch B, Harth V, Broede P, Fronhoffs S, Landt O, Brüning T, Abel J, Bolt HM, Herberhold C, Vetter H, Ko YD 
(2003) Association between head and neck cancer and microsomal epoxide hydrolase genotypes. Arch Toxicol 77:37-41

Wong RH, Hu CW, Yeh CY, Chao MR, Chen CC, Huang JH, Chang SH, Lee SI, Lee HS (2008) Sulfotransferase 1A1 and glutathione
$S$-transferase P1 genetic polymorphisms modulate the levels of urinary 8-hydroxy-2'-deoxyguanosine in betel quid chewers. Arch Toxicol 82:313-321 